\title{
SIMULATION OF INSOLVENCY PROCEEDINGS YEAR II - EVIDENCE OF THE LONG TERM EFFECT ON COGNITIVE LEARNING
}

\author{
Martina Krasnicka ${ }^{1}$, Viktor Vojtko², Zdenek Strnad ${ }^{1}$, Rudolf Hruby ${ }^{1}$ \\ ${ }^{1}$ Department of Law, Faculty of Economics, University of South Bohemia in České Budějovice, Branišovská \\ 1645/31a, 37005 České Budějovice, Czech Republic \\ ${ }^{2}$ Department of Trade and Tourism, Faculty of Economics, University of South Bohemia in České Budějovice, \\ Branišovská 1645/3la, 37005 České Budějovice, Czech Republic
}

\begin{abstract}
KRASNICKA MARTINA, VOJTKO VIKTOR, STRNAD ZDENEK, HRUBY RUDOLF. 2017. Simulation of Insolvency Proceedings Year II - Evidence of the Long Term Effect on Cognitive Learning. Acta Universitatis Agriculturae et Silviculturae Mendelianae Brunensis, 65(6): 1979-1985.

The aim of this paper is to draw some conclusions from a long-term project inspired by the so-called Mock trials experienced in the USA and applied into the Czech system of law education of students at the Faculty of Economics of the University of South Bohemia.

The project involves a simulation of insolvency proceedings in case of a company bankruptcy. The students play roles of the various participants in the insolvency proceedings and learn very relevant but rather complicated process of insolvency. The results of the second academic year involve re-testing of students included in the SIP 1.0 (Simulation of Insolvency Proceedings 2015/2016) in order to assess if the learning experience has the long-term impact and comparison with the new group of students that undergone the SIP 2.0 (Simulation of Insolvency Proceedings 2016/2017).
\end{abstract}

Keywords: simulation; mock trial; insolvency proceedings; company bankruptcy; long-term cognitive learning; education.

\section{INTRODUCTION}

In the context of law education and use of simulated trials, the American Mock Trial Association (www.collegemocktrial.org) began annual intercollegiate competitions in 1985. Business law professors have been writing scholarly articles about holding mock trials in their classrooms for almost as long (Bennett 1997, Lawton and Oswald 1993, Mann 1995, McDevitt 1998, Miller 1987). A purpose of the mock trial is to provide business students with the vocabulary and knowledge to interact with in-house counsel and outside counsel when disputes arise, just as students are educated about management information systems, not to become programmers, but to enhance their ability to work with professionals in the field (Miller 1987).

The benefits of mock trials according to various researchers (Karraker 1993, Lawton and Oswald 1993) include an improvement of critical thinking, increase of long-term retention of material, introduction to evaluations of the quality of evidence, promoting searches for cause-and-effect relationships, and forcing the pursuit of logical consistency. And also, student evaluations of the mock trial experience are traditionally positive (Miller 1987). Newer studies related to mock trials educational efficiency seem to be missing although previous studies suggest further research.

There are many different approaches that could be used to develop students' knowledge and skills and the use of simulation, i.e. educational imitation of real-world situations and tasks, is one of them. But it is not the only one and it is necessary to understand benefits and limitations of an efficient simulation use in education.

In accordance to the Bloom's taxonomy of learning objectives learning outcomes can be identified in the following three domains (Bloom et al. 1959, Krathwohl, Bloom and Masia, 
1964): cognitive (knowing), affective (feeling), and psychomotor (doing). Each of these domains has stages of learning unique to that domain. Research on the cognitive domain was aided by Gentry and Burns (1981), who provided descriptions of learning and the assessment process for the six levels in the cognitive domain - (1): basic knowledge, (2): comprehension, (3): application, (4): analysis, (5): synthesis, (6): evaluation - which should be supported by different tools and methods and also assessed differently. These descriptions have served as guides for researchers for the past 25 years.

The cognitive domain means to obtain and memorize terminology, factual knowledge, basic concepts, or principles, in other words the theory. The literature suggests that simulations' use is not a very efficient approach for such a task and traditional lectures and seminars could be more efficient in this sense, at least from short-term perspective which is typically assessed.

The second, affective domain basically includes improvement of students' attitudes toward the discipline and their greater involvement in the classroom work. For this perspective, literature suggests that active approaches such as simulation typically perform better in comparison to previously mentioned lectures.

Within the affective learning the subsequent research expanded into attempting to assess what is learned from participating in a simulation, rather than simply the perception of whether learning occurred. The research on behavioural (psychomotor) change during simulations has been limited but it involves according to Anderson and Lawton (2008) a number of studies that have focused on external validity by comparing success on a simulation with current business success. These longitudinal studies found some association between career success regarding salaries and promotions for students and performance on the simulation.

Kraiger, Ford and Salas (1993) based their approach on the Bloom's theory (besides number of other schools) and created a theoretically based model of learning outcomes that is multidimensional and has construct-oriented approach to learning - cognitive, skill-based, and affective outcomes. According to them the cognitive learning outcomes are divided into verbal (declarative) knowledge, knowledge organization and cognitive strategies. The topic of this paper lies in the second area - knowledge organization. It involves grouping meaningful pieces of information into mental models, which are then stored in long-term memory for later recall. That is, also according to Wilson et al. (2009), helpful within the next stage - cognitive strategies - when quickly solving new or novel problem ("application") or making judgements about information ("evaluation").

Anderson (2008) points out that it is still disappointing how little can be objectively demonstrated regarding what students learn from participating in simulation exercises and that we still are largely unable to document what simulation exercises accomplish in relation to the cognitive domain.

The essentially same conclusion reached earlier Greenlaw and Wyman (1973). They said it is very difficult to compare and contrast learning that occurs within simulations because of the absence of control groups and wide range of classroom practices for using business simulations. In connection to their research, Hsu (1989) suggested to have "clear and specific hypotheses on the specific learning objectives" that target managerial, technical, and problem-solving skills. Burns, Gentry and Wolfe (1990) also found an absence of rigorous research supporting the learning effectiveness of experiential methods such as business simulations. Gosenpud (1990) found studies that reported cognitive learning, but they either were based on perceptions of learning or they assessed the lower levels of the learning domain. The studies Gosenpud cited for assessing behavioural change/skill acquisition (the psychomotor domain) either suffered from ill-defined criterion measures or, again, were based on perceptions of behavioural change.

All categories of possible outcomes of using simulation have something in common; it has been difficult to devise a simple instrument and methodology that would measure the effectiveness of simulations and equally difficult to generalize the results of studies that assess the educational value of simulations (Anderson 2008).

However, there have been several recent studies (Huebscher and Lendner 2010, Duque and Weeks 2010, Avramenko 2012, Tiwari, Nafees and Krishnan 2014) that show how to systematically assess the impact of simulations and performance of students and especially use of new technologies could be a way forward.

From the literature review is quite clear, that the use of simulations in education might be beneficial if properly used, designed and assessed. But it is quite difficult to measure the benefits, especially in the long-term cognitive learning. In this context, we would like to enhance the present knowledge by our findings from undertaking such a simulation and assessment in the context of law education of business students at the Faculty of Economics, University of South Bohemia in Ceske Budejovice.

Hence, this article focuses particularly on long-term retention of insolvency topic in the case of business students and provides some answers to questions how efficient in the cognitive domain could be the simulation of insolvency proceedings in the long-term perspective.

\section{Research Methods and Procedures}

In the academic year 2015/16, we have used an experimental design based on posttest with the control and experimental group (Krásnická et al. 2016). Both groups were tested immediately after 
the end of the course/simulation of insolvency proceedings in January 2016 (Test 1.1) and the same students were re-tested approximately one year later - in December 2016 (Test 1.2).

Due to the study subject limitations it was not possible to randomly split students into experimental (EG) and control group (CG), we had to follow their affiliation with study programmes.

Students of the study program Accountancy and Financial Management of Enterprise and students of Economic Informatics formed the first experimental subgroup (UFRP), while the students of Management of Commerce study programme (OP) gave rise to the second experimental subgroup. As a part of the simulation they competed in a case of insolvency proceedings of the company.

Remaining students of the study programme Management and Business Economics (REP) were taught in classically led seminars. They served as a control group for the test on the efficiency of simulation of insolvency proceedings as the new teaching method. Both groups had also regular lectures.

The first task for the students involved in the experimental groups was to assess whether a company failure met criteria of being in bankruptcy according the Czech Insolvency Act, i.e. a situation the graduates of the Faculty of Economics can easily face in their practice. For this purpose, a case study of a construction company was prepared and introduced to the students.

In the next phase, students of both experimental subgroups were randomly divided into three teams - "debtors", "secured creditors" and "unsecured creditors". Each of the teams was asked to take its' position in the abovementioned case of the construction company failure and to try to defend it before a jury better than the mirror team from the other experimental subgroup.

The simulation itself then was carried out at the premises of the Regional Court in Czech Budejovice. The jury consisted of a real judge, two insolvency practitioners, three members of the Department of Law and one member of the Department of Trade and Tourism of the Faculty of Economics. The jury for the individual subgroups evaluated the quality of insolvency proposals (submitted by the debtor subgroups) and insolvency applications (submitted by secured and unsecured creditors subgroups). Subsequently they judged queries to an insolvency practitioner (played by the real insolvency practitioner) asked by all subgroups, the creditors' voting on the choice of their new insolvency practitioner and on the procedure of solving the debtor's failure.

The guarantor of the subject Business Law II then prepared the anonymous test. She led the control group and participated in the simulation only as a jury member. It contained ten $\mathrm{ABC}$ type questions. The test was given to both experimental groups and to the control group after the simulation had been finished and without prior notice in January 2016
(Test 1.1). As mentioned above, the same anonymous test was given to the same students in December 2016, again without prior notice (Test 1.2) and its' aim was to particularly evaluate the long-term retention of simulation topic knowledge. The Simulation of Insolvency Proceedings 1.0 was finished by this test.

The Simulation of Insolvency Proceedings 2.0 has started in the academic year 2016/17 and thus new students (one year "younger") have been included. In this case, we were able to randomly split students from different study programs to the experimental and control groups. The process of the course was practically identical with the previous academic year, however the anonymous test (marked as 2.1) was longer and more detailed. Six questions were identical with the test which was used for the previous group (1.1). This round of simulation will be ended in December 2017 (by the test 2.2) however some preliminary results concerning those six identical question are included in the discussion of this paper as well.

In accordance with the literature review the following research question has been selected: does the simulation of insolvency proceedings significantly help in the second stage of learning outcomes according to Kraiger, Ford and Salas (1993) - the knowledge organization - in terms of retention of information in the long-term perspective?

In order to answer this research question the following hypothesis was formulated:

$\mathrm{Hl}$ : The performance of students who participated in the simulation (experimental group) will be 11 months after the simulation better than the performance of students who did not participate in the simulation (control group, traditional teaching).

The independent variable in our experiment was the performance in the final test. The dependent variable was the simulation experience. In order to evaluate how effective this method was the students participated in a survey that involved an anonymous final test immediately after the simulation/course (January 2016, Test 1.1). The aim of the test was to evaluate and compare the level of cognitive skills at the first and second level of Bloom's taxonomy of learning objectives, i.e. the basic knowledge and comprehension.

The same anonymous test was given to the same students in December 2016, again without prior notice (Test 1.2.) and its aim was particularly evaluate the long-term retention of simulation topic.

For the data analysis, Excel and $\mathrm{R}$ software package ( $\mathrm{R}$ Core Team, 2016) have been used, statistical testing of differences has been done by nonparametric Kruskal-Wallis (K-W) test of differences between median values (with assumptions tested by Fligner-Killeen test of homogeneity of variances and also fulfilled in all below used cases) and chi-square $\left(\chi^{2}\right)$ test. 


\section{RESULTS}

In the first step we analyzed how many students correctly answered the individual questions of the tests

Statistically significant differences between the experimental group and control group (for $\alpha=0.05$, tested by $\chi^{2}$ test) were found in the questions No. 1 and No. 5

As for the question No.5, according to the $\chi^{2}$ test, the differences between experimental and control groups were statistically significant in both tests ( $p$-value $=0.028$ for the test $1.1 ; p$-value $=0.03627$ for the test 1.2). As also noted above, the test questions were prepared by the subject guarantor, who did not participate in the simulation of insolvency and led the control group in a traditional way.

The subject of the traditional seminars was mainly to prepare an insolvency proposal and to fill in an insolvency application. Better performance of the control group could be seen for the question No. 5 related to the proposal for insolvency, but only shortly after the subject (test 1.1). These control group students answered it correctly in 87\% compared to $64.2 \%$ correct answers in the experimental group. After 11 months, the students of experimental group slightly improved (69.8\% of correct answers) however the results of the control group were significantly ${ }^{1}$ worse (44\% of correct answers). The students from the control group significantly worsened $\left(\chi^{2} \mathrm{p}\right.$-value $\left.=0.003257\right)$ probably due to the weaker retention of knowledge caused by traditional way of learning. The lower number of students (43 filled the test 1.2 instead of 53 in the test 1.1) could cause the (surprising) improvement in the results of the experimental group.

The opposite situation is in the case of question No. 1 related to a procedure of solving the company insolvency. This question was not addressed during the preparation for simulation of insolvency proceedings at all. However, during the actual simulation, in which students played roles of insolvency proceedings participants, different groups of creditors voted on it. Thus, this question was only introduced to the participants as part of the game and the experimental groups answered it in the test 1.1 correctly in $94.3 \%$ (test 1.1 ) and in $95.3 \%$ (test 1.2) compared to $73.3 \%$ (test 1.1) and $64 \%$ (test 1.2) of correct answers in the control group ${ }^{2}$. Thus, according to the $\chi^{2}$ test, the differences between the experimental and control groups were statistically significant in both tests $(p$-value $=0.007$ for the test $1.1 ; \mathrm{p}$-value $=0.000712$ for the test 1.2). Similar results can be observed in other issues, although the differences are not statistically significant.

In the next step we focused on the total number of correct answers (maximum $=10$ ) in both tests.
The differences were analyzed between the tests (vertically in the Tab. IV) and between the groups (horizontally in the Tab. IV).

In the test 1.1 the difference in the overall results between experimental and control groups was quite small. The control group, whose participants were taught by classic seminars, had an average of 7.90 correct answers (median $=8$ ) and the experimental group 7.64 (median $=8$ ). If we statistically test the difference for medians, it is not statistically significant (K-W $\mathrm{p}$-value $=0.2513)$ and thus the difference is very small to be generalized to a broader population. Therefore, one year ago, we could not fully confirm or refuse the findings of various studies summarized by Anderson (2008) saying that the teaching of basics concepts and terminology is more effective in the form of lectures and seminars but the findings generally supported that, even though very weakly.

In the test 1.2, the control group had an average of 7.03 correct answers (median $=8$ ) and the experimental group 7.73 correct answers (median =6). Unlike in the previous year this result is statistically significant ( $\mathrm{K}-\mathrm{W}$ p-value $=0.0005292$ ).

From the Tab. IV it is also clear that the students from the experimental group improved. The probable reason for the improvement of the EC has already been mentioned - there were 10 students less in the re-testing and we can assume that the weaker students left their studies. However, this improvement is not statistically significant (K-W $\mathrm{p}$-value $=0.6783$ )

Based on the data above we can confirm our hypothesis $\mathrm{HI}$ that the performance of students who participated in the simulation (experimental group) was 11 months after the simulation better than the performance of students who did not participate in the simulation (control group, traditional teaching). The result is statistically significant on the level of significance $\alpha<0.01$ (K-W $\mathrm{p}$-value $=0.0005292$ ).

\section{DISCUSSION}

When comparing the previous studies from the cognitive learning perspective with ours, they generally fit together quite well - especially with Kraiger, Ford and Salas (1993) and Anderson and Lawton (2008). As has been shown while testing hypothesis $\mathrm{Hl}$, long-term learning has been much better for the experimental group and quite interesting is also the overall result which basically showed no erosion of knowledge for the simulation experience participants. Our study is in this respect relevant mainly because all the previously mentioned studies have been done in other cultures, predominantly in the U.S. and UK.

Nevertheless, it is also necessary to mention few limitations of this study. Firstly, it was not possible 
I: Differences in the final test answers between experimental group (EG) and control group (CG)

\begin{tabular}{|c|c|c|c|c|c|c|c|}
\hline \multicolumn{4}{|c|}{ Test $1.1(n=83)$} & \multicolumn{4}{|c|}{ Test $1.2(n=68)$} \\
\hline $\begin{array}{c}\text { Test } \\
\text { question }\end{array}$ & $\begin{array}{c}\text { Proportion } \\
\text { of right } \\
\text { answers - EG } \\
(n=53) \\
\end{array}$ & $\begin{array}{c}\text { Proportion } \\
\text { of right } \\
\text { answers - CG } \\
(n=30) \\
\end{array}$ & $\begin{array}{c}\chi^{2} \text { test } \\
\text { p-value }\end{array}$ & $\begin{array}{c}\text { Test } \\
\text { question }\end{array}$ & $\begin{array}{c}\text { Proportion } \\
\text { of right } \\
\text { answers - EG } \\
(n=43) \\
\end{array}$ & $\begin{array}{c}\text { Proportion } \\
\text { of right } \\
\text { answers - CG } \\
(n=25) \\
\end{array}$ & $\begin{array}{c}\chi^{2} \text { test } \\
\text { p-value }\end{array}$ \\
\hline 1 & $94.3 \%$ & $73.3 \%$ & 0.007 & 1 & $95.3 \%$ & $64.0 \%$ & 0.000712 \\
\hline 2 & $96.2 \%$ & $86.7 \%$ & 0.106 & 2 & $93.0 \%$ & $76.0 \%$ & 0.04579 \\
\hline 3 & $92.5 \%$ & $70.0 \%$ & 0.007 & 3 & $67.4 \%$ & $80.0 \%$ & 0.2658 \\
\hline 4 & $81.1 \%$ & $90.0 \%$ & 0.286 & 4 & $81.4 \%$ & $56.0 \%$ & 0.02443 \\
\hline 5 & $64.2 \%$ & $86.7 \%$ & 0.028 & 5 & $69.8 \%$ & $44.0 \%$ & 0.03627 \\
\hline 6 & $88.7 \%$ & $93.3 \%$ & 0.490 & 6 & $83.7 \%$ & $92.0 \%$ & 0.3314 \\
\hline 7 & $47.2 \%$ & $66.7 \%$ & 0.087 & 7 & $51.2 \%$ & $24.0 \%$ & 0.0282 \\
\hline 8 & $30.2 \%$ & $53.3 \%$ & 0.037 & 8 & $32.6 \%$ & $44.0 \%$ & 0.3454 \\
\hline 9 & $79.2 \%$ & $93.3 \%$ & 0.090 & 9 & $95.3 \%$ & $84.0 \%$ & 0.1116 \\
\hline 10 & $90.6 \%$ & $76.7 \%$ & 0.084 & 10 & $79.1 \%$ & $60.0 \%$ & 0.09107 \\
\hline
\end{tabular}

II: Statistically significant differences between experimental group (EG) and control group (CG)

\begin{tabular}{|c|c|c|}
\hline Test question & TEST 1.1 & TEST 1.2 \\
\hline 1 & YES & YES \\
\hline 2 & NO & YES \\
\hline 3 & YES & NO \\
\hline 4 & NO & YES \\
\hline 5 & YES & YES \\
\hline 6 & NO & NO \\
\hline 7 & NO & YES \\
\hline 8 & YES & NO \\
\hline 9 & NO & NO \\
\hline 10 & NO & NO \\
\hline
\end{tabular}

III: Number of students in the Test 1.1. and Test 1.2

\begin{tabular}{lccc}
\hline \multicolumn{1}{c}{ Number of students } & January 2016 (Test 1.1) & December 2016 (Test 1.2) & Test 1.2/ Test 1.1 \\
\hline Experimental Group & 53 & 43 & $81,1 \%$ \\
Control Group & 30 & 25 & $83,3 \%$ \\
Total & 83 & 68 & $81,9 \%$ \\
\hline
\end{tabular}

IV: Total number of correct answers in the test 1.1 and 1.2

\begin{tabular}{|c|c|c|c|c|c|c|}
\hline & $\begin{array}{l}\text { Experimental } \\
\text { group (EG) }\end{array}$ & $\mathbf{n}$ & $\begin{array}{l}\text { Control } \\
\text { group (CG) }\end{array}$ & $\mathbf{n}$ & K-W p-value & $\begin{array}{c}\text { Statistical } \\
\text { significance } \\
(\alpha=0.05)\end{array}$ \\
\hline test 1.1 & 7.64 & 53 & 7.9 & 30 & 0.2513 & NO \\
\hline test 1.2 & 7.73 & 43 & 7.03 & 25 & 0.005292 & YES \\
\hline K-W p-value & 0.6783 & & 0.0003257 & & & \\
\hline Statistical significance $(\alpha=0.05)$ & NO & & YES & & & \\
\hline \multicolumn{7}{|c|}{ V: Total number of correct answers in six questions of the test 1.1 and 2.1} \\
\hline $\begin{array}{l}\text { 1.1 - Test questions No. } 1,2,3,4,5,9 \\
2.1 \text { - Test questions No. } 1,2,3,4,5,8\end{array}$ & $\begin{array}{l}\text { Experimental } \\
\text { group (EG) }\end{array}$ & $\mathbf{n}$ & $\begin{array}{l}\text { Control } \\
\text { group (CG) }\end{array}$ & $\mathbf{n}$ & K-W p-value & $\begin{array}{c}\text { Statistical } \\
\text { significance } \\
(\alpha=0.05)\end{array}$ \\
\hline 1.1 & 5.08 & 53 & 5.00 & 30 & 0.8994 & NO \\
\hline 2.1 & 5.63 & 35 & 5.68 & 76 & 0.3273 & NO \\
\hline K-W p-value & 0.0057 & & 0.0002 & & & \\
\hline Statistical significance $(\alpha=0.05)$ & YES & & YES & & & \\
\hline
\end{tabular}


in this case to use the true experimental design with randomization of participants. But to comment that, we have found no clues that the group composition would have any significant impact on the results. For the future studies, this has been sorted out in the second round of data collection (SIP 2.0). Secondly, anonymous tests did not allow us to compensate for other external variables like study results etc. This is again partially solved in the newer version of additional questionnaire which contains also other questions, e.g. about time being spent or 5-point Likert scale statements about participants' attitudes towards the simulation pedagogy and its' effect on their skills. Anyway, we are not aware of any shortcomings that would significantly biased the findings.

For the purpose of the planned Simulation of Insolvency Proceedings 3.0 it is also interesting the compare the results of tests from the SIP 1.0 and 2.0. The basic difference is that the students for the experimental group were selected from the whole group of students $(n=111)$ in relation to their performance in preparation of insolvency proposal (independently on their study program). The test was again anonymous but unlike in the SIP 1.0 it was not given to the students of the control group without prior notice. So, they came prepared for the final test.

It is possible to directly compare only the same questions in both tests in SIP 1.0 and SIP 2.0. These were questions No. 1 to No. 5 and then question No. 9 that was in the test 2.1 placed differently as No. 8.

As the Tab. V shows, differences between the test results right after the simulation (1.1 and 2.1) are statistically significant for both groups. The better and well-motivated students became a part of the experimental group and the control group was prepared and motivated by the need of successful finishing of the subject.

In this context, we also expect very interesting results from the test 2.2 that will re-test the students from the SIP 2.0 in December 2017. In general, significant worsening of the control group is expected. What remains unclear is whether the students of experimental group would (again) provide us with practically the same number of correct answers as in the test 1.2 considering the fact that their answers were significantly better than of their colleagues from the SIP 1.0 - on the reasons was probably also a change in delivering the subject content due to educators' experience from the SIP 1.0.

VI: Total number of correct answers in six questions of the test 1.1 and 1.2

\begin{tabular}{lcccccc}
\hline Test questions No. 1,2,3,4,5 and 9 & $\begin{array}{c}\text { Experimental } \\
\text { group (EG) }\end{array}$ & $\mathbf{n}$ & $\begin{array}{c}\text { Control } \\
\text { group (CG) }\end{array}$ & $\mathbf{n}$ & K-W p-value & $\begin{array}{c}\text { Statistical } \\
\text { significance } \\
(\boldsymbol{\alpha}=\mathbf{0 . 0 5})\end{array}$ \\
\hline test 1.1 & 5.08 & 53 & 5.00 & 30 & 0.8994 & NO \\
test 1.2 & 5.02 & 43 & 4.04 & 25 & 0.0007 & YES \\
K-W p -value & 0.5325 & & 0.0020 & & & \\
Statistical significance $(\boldsymbol{\alpha}=\mathbf{0 . 0 5})$ & NO & YES & & & \\
\hline
\end{tabular}

\section{CONCLUSION}

In our study, we have assessed the learning outcomes of simulation of insolvency proceedings from learning objectives cognitive domain perspective, which was recommended by previous mock trial studies (Gershuny, McAllister and Rainey 2012).

The results generally support previous theoretical findings about positive long-term effect of the simulation experience on learning. As tested in the hypothesis $\mathrm{Hl}$, this result is statistically significant on $\alpha<0.01$ and thus quite robust. We can conclude that the insolvency proceedings simulation experience has had a positive effect on the long-term learning of participants and we can recommend to use this pedagogy wider.

Our study is in this respect relevant mainly because all the previously mentioned studies have been done in other cultures, predominantly in the U.S. and UK.

For these reasons, we can recommend this pedagogy for wider use by law educators, not only for business students, but for others as well. And probably not only from the insolvency proceedings point of view but also in other areas of law.

This study also opens up few directions for the future research. One of them should be the research in other abovementioned learning domains - i.e. behavioral and affective. Another one should be replication of the long-term learning effects with different educators, students, team settings and learning environments (e.g. the real court room vs e-learning) to decrease effect of third variables that are now not under control of the researchers and to make this experience accessible to larger audience. 
Acknowledgements

This work was supported by the Ministry of Education, Youth, and Sport of the Czech Republic - university specific research.

\section{REFERENCES}

ANDERSON, P. H. and LAWTON, L. 2008. Business Simulations and Cognitive Learning: Developments, Desires, and Future Directions. Simulation $\sigma^{\circ}$ Gaming, 40(2): 193-216.

AVRAMENKO, A. 2012. Enhancing students' employability through business simulation. Education and Training, 54(5): 355-367.

BENNETT, R. B., LEIBMAN, J. H. and FETTER, R. E. 1997. Using a Jury Simulation as a Classroom Exercise. Journal of Legal Studies Education, 15(2): 191-210.

BLOOM, B. S., ENGLEHART, M. D., FURST, E. D. et al. 1959. Taxonomy of educational objectives: The classification of educational goals. Handbook 1: The cognitive domain. New York: David McKay.

BURNS, A. C., GENTRY, J. W. and WOLFE, J. 1990. A cornucopia of considerations in evaluating the effectiveness of experiential pedagogies. In: GENTRY, J. W. (Ed.). Guide to business gaming and experiential learning. East Brunswick, NJ: Nichols/GP Publishing, pp. 253-278.

DUQUE, L. C. and WEEKS, J. R. 2010. Towards a model and methodology for assessing student learning outcomes and satisfaction. Quality Assurance in Education, 18(2): 84-105.

GENTRY, J. W. and BURNS, A. C. 1981. Operationalizing a test of a model of the use of simulation games and experiential learning. Developments in Business Simulation and Experiential Learning, 8: 48-52.

GERSHUNY,P., MCALLISTER,C.andRAINEY,C.2012.MockTrials Versus Managementor Litigation-Driven Models of Business Law Instruction. Journal of Education for Business, 87(4): 193-197.

GOSENPUD, J. J. 1990. Evaluation of experiential learning. In: GENTRY, J. W. (Ed.). Guide to business gaming and experiential learning. East Brunswick, NJ: Nichols/GP Publishing, pp. 301-329.

GREENLAW, P. S. and WYMAN, F. P. 1973. The Teaching Effectiveness of Games in Collegiate Business Courses. Simulation $\sigma$ Gaming, 4(3): 259-294.

HSU, E. 1989. Role-Event Gaming Simulation in Management Education: A Conceptual Framework and Review. Simulation and Games, 20(4): 409-38.

HUEBSCHER, J. and LENDNER, C. 2010. Effects of Entrepreneurship Simulation Game Seminars on Entrepreneurs' and Students' Learning. Journal of Small Business and Entrepreneurship, 23(4): 543-554.

KARRAKER, M. W. 1993. Mock trials and critical thinking. College Teaching, 41(4): 134-137.

KRAIGER, K., FORD, J. and SALAS, E. 1993. Application of cognitive, skill-based, and affective theories of learning outcomes to new methods of training evaluation. Journal of Applied Psychology, 78(2): 311-328

KRÁSNICKÁ, M., VOJTKO, V., STRNAD, Z. and HRUBÝ, R. 2016. Learning outcomes of simulation of insolvency proceedings inspired by the US Mock trials. Acta Universitatis Agriculturae Et Silviculturae Mendelelianae Brunensis 64(6): 1951-1959.

KRATHWOHL, D. R., BLOOM, B. S. and MASIA, B. B. 1964. Taxonomy of educational objectives: The classification of educational goals. Handbook II: The affective domain. New York: David McKay.

LAWTON, A. M. and OSWALD, L. J. 1993. The use of simulated hearings in business law courses. Journal of Legal Studies in Education, 11: 103-126.

MANN, S. K. 1995. A Simulated Hearing Modified for Teaching Business Law to Graduate Business Students. Journal of Legal Studies in Education, 13(2): 311-316.

MCDEVITT, W. J. 1998. Three Ready-to-Use Mock Jury Trials for the Classroom. Journal of Legal Studies Education, 16(1): 149-171.

MILLER, C. J. 1987. Mock Jury Trial: A Model for Business Law I Courses. Journal of Legal Studies Education, 6(1): 91-94.

TIWARI, S. R., NAFEES, L. and KRISHNAN, O. (2014). Simulation as a pedagogical tool: Measurement of impact on perceived effective learning. The International Journal of Management Education, 12(3): 260-270.

WILSON, K. A., BEDWELL, W. L., LAZZARA E. H., SALAS E., BURKE C. S., ESTOCK J. L., ORWIS K. L. and CONKEY C. 2008. Relationships Between Game Attributes and Learning Outcomes: Review and Research Proposals. Simulation $\sigma$ Gaming, 40(2): 217-266.

Contact information

Martina Krasnicka: mkrasnicka@ef.jcu.cz

ViktorVojtko:vojtko@ef.jcu.cz

Zdenek Strnad: zstrnad@ef.jcu.cz

Rudolf Hruby: hruby@ef.jcu.cz 